\title{
Micronutrients in biomass fractions of holm oak, beech and fir forests of the Montseny massif (Catalonia, NE Spain)
}

\author{
A Caritat ${ }^{\star}, \mathrm{J}$ Terradas \\ CREAF, Facultat de Ciencies, Universitat \\ Autonoma de Barcelona, 08193 Bellaterra, Barcelona, Spain \\ (Received 24 July 1989; accepted 28 February 1990)
}

\begin{abstract}
Summary - This study is part of a larger research programme on different forest ecosystems in the Montseny massif (Barcelona, NE Spain). The contents of 4 micronutrients ( $\mathrm{Mn}, \mathrm{Fe}, \mathrm{Zn}$ and $\mathrm{Cu}$ ) are given for some biomass fractions in individual monospecific stands of holm oak (Quercus ilex $L$ ), beech (Fagus sylvatica $L$ ) and fir (Abies alba). The behaviour of different micronutrients is related to relative mobility. $\mathrm{Mn}, \mathrm{Fe}$ and $\mathrm{Zn}$ concentrations increase with leaf age. Nutrient levels of the Montseny stands are compared with those found in other forests of the same species. We have observed relatively high $\mathrm{Mn}$ concentrations in different biomass fractions of the holm oak forest studied. This can be related to the low soil $\mathrm{pH}$ values. Our 3 forests show different micronutrient allocational patterns. Total quantities of the micronutrients in the biomass are only calculated for $Q$ ilex forest. Values found are $33.6 \mathrm{~kg} \mathrm{Mn} / \mathrm{ha}$, $15.0 \mathrm{~kg} \mathrm{Fe} / \mathrm{ha}, 2.8 \mathrm{~kg} \mathrm{Zn} / \mathrm{ha}$ and $0.17 \mathrm{~kg} \mathrm{Cu} / \mathrm{ha}$.
\end{abstract}

\section{biomass fraction / micronutrient / Quercus ilex / Fagus sylvatica / Abies alba}

\begin{abstract}
Résumé - Éléments traces dans la biomasse de la chênaie, de la hêtraie et de la sapinière du massif de Montseny. Ce travail fait partie d'une etude sur les differents écosystèmes forestiers du massif de Montseny (Barcelone, NE, Espagne). La composition en Mn, Fe, Zn et $\mathrm{Cu}$ de differents compartiments de la biomasse est analysee pour des parcelles monospécifiques de chêne vert (Quercus ilex), de hêtre (Fagus sylvatica) et de sapin (Abies alba). Les concentrations en $\mathrm{Mn}$, Fe et $\mathrm{Zn}$ augmentent au cours du vieillissement de la feuille. Les niveaux de ces concentrations ont été comparés pour les especes correspondant à celles d'autres forêts. Le niveau du Mn est relativement élevé dans les différents compartiments des arbres de l'especce chêne vert. Cette différence est à mettre en relation avec la basse valeur du $\mathrm{pH} d u$ sol. $A$ chacune des 3 forêts étudiées correspond un type différent de répartition de ces éléments traces.
\end{abstract}

\footnotetext{
" Correspondence and reprints. Present address: Estudi General de Girona, Laboratori del suro, C/ Hospital, 6 -17071- Girona, Spain
} 
L'immobilisation totale dans la biomasse de ces eléments traces n'a été calculée que pour le peuplement de chêne vert. Elle est évaluée pour le $\mathrm{Mn}$, le Fe, le $\mathrm{Zn}$ et le Cu respectivement à $33,6,15,0,2,8$ et $0,17 \mathrm{~kg} / \mathrm{ha}$.

\section{compartiment de la biomasse / élément trace / Quercus ilex / Fagus sylvatica / Abies alba}

\section{INTRODUCTION}

Studies on mineral element cycling in forest ecosystems have focused mainly on the major nutrients. Data on micronutrients are relatively scarce, and most aspects of the role of micronutrients in ecosystems' components are poorly understood. We know that micronutrients accumulate in highly metabolically active parts of the plant, like leaves and twigs, because of their involvement in enzymatic reactions within coenzyme molecules (Kramer and Kozlowski, 1979). Concentrations of the relatively immobile elements increase with the age of leaves, probably due to a passive accumulation in the transpiration flow and to relatively low absorption rates (Larcher, 1977). The lowest concentrations are found in wood; nevertheless, wood is the biomass fraction containing the greatest quantity of micronutrients, simply because it is the largest one. Concentrations usually decrease as the stem diameter increases. Bark is an area of accumulation and usually has high micronutrient concentrations (Denaeyer De Smet, 1971).

As occurs frequently with major nutrients, rates of change and total content of oligoelements vary greatly among species. The aim of this study was to determine the levels of 4 micronutrients ( $\mathrm{Mn}, \mathrm{Fe}, \mathrm{Zn}$ and $\mathrm{Cu}$ ) in the different biomass fractions of holm oak (Quercus ilex), beech (Fagus sy/vatica) and silver fir (Abies alba), growing in monospecific forest canopies, in 3 different stands of the Montseny range in northern Spain, and also to look for differences related to the life cycles and leaf morphology in these 3 species by comparing the micronutrient contents of the various biomass fractions.

\section{THE STUDY AREA}

The experimental plots are located in the Montseny massif, about $40 \mathrm{~km} \mathrm{NNE}$ of Barcelona.

The evergreen oak plot $\left(41^{\circ} 16^{\prime} \mathrm{N}\right.$, $2^{\circ} 21^{\prime} \mathrm{E}, 665 \mathrm{~m}$ asl) measures $0.23 \mathrm{ha}$ and lies within La Castanya Biological Experimental Station, at the foot of a rough mountain slope $\left(30^{\circ}\right)$. The slope in the plot is slight, varying from 7 to $23^{\circ}$, and the orientation is $W$ and NW. The bedrock consists of a metamorphic schist, and the soil is a ranker $(U 2 \mathrm{~b} / \mathrm{c}$, gravelly phase) associated with a dystric cambisol (Bd). Mean annual precipitation is around $900 \mathrm{~mm}$ and mean annual air temperature is $9-10^{\circ} \mathrm{C}$. The tree layer is dense and formed exclusively of Quercus ilex. The basal area was $26.6 \mathrm{~m}^{2} / \mathrm{ha}$ in 1979 . There were 2100 stems/ha with a DBH > 5 $\mathrm{cm}$ and 536 stems with $\mathrm{DBH}>15 \mathrm{~cm}$. The dominant trees were $9-12 \mathrm{~m}$ in height and had an estimated age of $60-90$ years.

The beech plot $\left(41^{\circ} \cdot 46^{\prime} \mathrm{N}, 2^{\circ} 28^{\prime} \mathrm{E}\right.$, $1165 \mathrm{~m}$ asl) measures 0.12 ha and is located in the Santa Fe Valley. The slope is gentle $\left(5^{\circ}\right)$. The bedrock is a 
deep altered granodiorite, and the soil is a dystric-humic cambisol ( $\mathrm{Bd}-\mathrm{Bh}$, 1 a). Mean annual precipitation is about $1200 \mathrm{~mm}$ (Rod, 1983) and average air temperature is $8-9^{\circ} \mathrm{C}$. The canopy is dense and consists of Fagus sylvatica with some isolated individuals of $/ l e x$ aquifolium as subdominants. The basal area was $26.7 \mathrm{~m}^{2} / \mathrm{ha}$ in 1980 . There are 1460 stems/ha with a DBH $>5 \mathrm{~cm}$ and 625 stems/ha with $\mathrm{DBH}>15 \mathrm{~cm}$. The dominant trees are $16-20 \mathrm{~m}$ in height and $50-60$ years old. The last tree thinning was carried out between 15 to 30 years ago.

The fir plot $\left(41^{\circ} 47^{\prime} \mathrm{N}, 2^{\circ} 27^{\prime} \mathrm{E}\right.$, $1355 \mathrm{~m} \mathrm{asl}$ ) is in the Passavets fir forest. It measures 0.12 ha and is situated on a NNW slope. The bedrock is a hornfels and the soil is a ranker ( $U 2 \mathrm{~d}$, stony phase) associated with dystric lithosols. The mean annual precipitation is $1200 \mathrm{~mm}$ and the mean temperature is $7-8{ }^{\circ} \mathrm{C}$. The tree layer is dense and is composed entirely of Abies alba Mill. The basal area was $42.4 \mathrm{~m}^{2} / \mathrm{ha}$ in 1980 . There were 567 stems/ha with a $\mathrm{DBH}>$ $5 \mathrm{~cm}$ and 467 stems/ha with $\mathrm{DBH}>15$ $\mathrm{cm}$. The dominant trees were 21-25 $\mathrm{m}$ in height and from 120-160 years old.

\section{METHODS}

For the holm oak forest (La Castanya stand) we used the field samples of the biomass fractions collected previously by Ferres (1984). These samples, obtained from 15 trees from even stem diameter class, were divided into: leaves (separated into age classes); 1 or 2 year-old twigs of $0-1 \mathrm{~cm}$ diameter (bark included); wood from the branches (divided into $1 \mathrm{~cm}$ diameter classes); wood from the boles, and bark from the branches and boles. We took additional bole wood samples from 10 trees with a Pressler borer.

In the beech stand (Santa $\mathrm{Fe}$ ) we collected samples of leaves, twigs and thin wood from 10 trees (September 1983). In the fir forest (Passavets) we collected samples of leaves, 1-5 yr-old branches and wood boles belonging to 3 fir trees.

Buiked samples of each biomass fraction from the different trees in each plot were analysed. They were dried to constant weight at $80^{\circ} \mathrm{C}$. $\mathrm{Mn}, \mathrm{Fe}, \mathrm{Zn}$ and $\mathrm{Cu}$ were analysed by atomic absorption with a PYE UNICAM Sp-1900 (Spectroscopy Service, Barcelona University) after acid digestion, following the methods described by Allen et al (1974) for $\mathrm{Mn}, \mathrm{Fe}$ and $\mathrm{Zn}$. For $\mathrm{Cu}$, due to the low concentrations, it was necessary to adopt a different procedure: the samples were digested with $\mathrm{HNO}_{3}$ and $\mathrm{HClO}_{4}$ on a hot plate, gradually increasing the temperature to $210^{\circ} \mathrm{C}$ and maintaining it at this level to the end of the digestion. These Cu analyses were carried out in the Department of Soil Science of the University of Aberdeen.

The micronutrient concentrations were analysed in order to determine individual tree variability in the different biomass fractions of $11 \mathrm{holm}$ oaks. The variability of the different elements is less than $12 \%$ in all the biomass fractions except in the stem wood where it is between 12 and $22 \%$. Total micronutrient quantities have been calculated from the biomass values obtained by dimensional analysis (Ferres, 1984) and micronutrient concentrations.

\section{RESULTS AND DISCUSSION}

\section{Micronutrient concentrations}

The concentrations in the different fractions agree with the general trends discussed in the introduction, as can be seen in table 1 .

In the holm oak, we can combine our data with those of Ferres (1984) for major nutrients to obtain the following nutrient ranking: $\mathrm{Ca}>\mathrm{N}>\mathrm{K}>\mathrm{Mg}-$ $\mathrm{P}>\mathrm{Mn}>\mathrm{Fe}>\mathrm{Na}>\mathrm{Zn}>\mathrm{Cu}$. In the cases of the beech and fir stands, we lack similar data on the major nutrients, but the micronutrient ranking is identi- 
Table I. Average concentrations (ppm) of $\mathrm{Mn}, \mathrm{Fe}$ and $\mathrm{Zn}$ in the different biomass fractions of the evergreen oak, fir and beech forests of Montseny.

\begin{tabular}{|c|c|c|c|c|}
\hline & $M n$ & $\mathrm{Fe}$ & $Z n$ & $\mathrm{Cu}$ \\
\hline & \multicolumn{4}{|c|}{$p p m$} \\
\hline \multicolumn{5}{|l|}{ Holm oak } \\
\hline $\begin{array}{l}\text { New leaves } \\
\text { Leaves } 1 \text {-year-old } \\
\text { Leaves } 2 \text {-years-old } \\
\text { Leaves total }\end{array}$ & $\begin{array}{r}667 \\
1137 \\
1498 \\
977\end{array}$ & $\begin{array}{l}120 \\
183 \\
203 \\
159\end{array}$ & $\begin{array}{l}29 \\
34 \\
42 \\
32\end{array}$ & $\frac{8.4}{3.9}$ \\
\hline $\begin{array}{l}\text { Twigs of the same year } \\
\text { Twigs } 1 \text {-year-old } \\
\text { Twigs } 2 \text {-years-old } \\
\text { Twigs total }\end{array}$ & $\begin{array}{l}575 \\
489 \\
445 \\
475\end{array}$ & $\begin{array}{l}191 \\
281 \\
226 \\
229\end{array}$ & $\begin{array}{l}30 \\
34 \\
29 \\
29\end{array}$ & $\begin{array}{l}- \\
8.4 \\
8.4\end{array}$ \\
\hline $\begin{array}{l}\text { Wood } 00-1 \mathrm{~cm} \\
\text { Wood } 01-5 \mathrm{~cm} \\
\text { Wood } 0>=5 \mathrm{~cm} \\
\text { Wood total }\end{array}$ & $\begin{array}{r}281 \\
85 \\
57 \\
97\end{array}$ & $\begin{array}{r}131 \\
42 \\
106 \\
99\end{array}$ & $\begin{array}{r}22 \\
12 \\
7 \\
10\end{array}$ & $\begin{array}{l}5.4 \\
- \\
0.8\end{array}$ \\
\hline $\begin{array}{l}\text { Bark } \\
\text { Inflorescences } \\
\text { Acorns }\end{array}$ & $\begin{array}{l}447 \\
614 \\
551\end{array}$ & $\begin{array}{r}186 \\
144 \\
42\end{array}$ & $\begin{array}{l}33 \\
42 \\
14\end{array}$ & 5.4 \\
\hline \multicolumn{5}{|l|}{ Fir } \\
\hline $\begin{array}{l}\text { Branches } 1 \text {-year-old } \\
\text { Branches } 5 \text {-years-old } \\
\text { Leaves } 1 \text {-year-old } \\
\text { Leaves } 5 \text {-years-old }\end{array}$ & $\begin{array}{l}312 \\
295 \\
202 \\
421\end{array}$ & $\begin{array}{l}257 \\
463 \\
113 \\
198\end{array}$ & $\begin{array}{l}50 \\
48 \\
31 \\
46\end{array}$ & $\begin{array}{l}\overrightarrow{6.9} \\
2.3 \\
2.3\end{array}$ \\
\hline Stem wood & 21 & 15 & 10 & 0.8 \\
\hline \multicolumn{5}{|l|}{ Beech } \\
\hline $\begin{array}{l}\text { Leaves } \\
\text { Stem wood } \\
\text { Twigs }\end{array}$ & $\begin{array}{l}618 \\
139 \\
196\end{array}$ & $\begin{array}{r}212 \\
48 \\
124\end{array}$ & $\begin{array}{l}36 \\
28 \\
43\end{array}$ & $\begin{array}{l}5.4 \\
6.9 \\
3.9\end{array}$ \\
\hline
\end{tabular}

cal. Concentrations in the individual biomass components are as follows.

\section{Leaves}

In the holm oak, Fe concentrations in the leaves are similar to these found in the Rouquet (Rapp, 1971) and Zn concentrations are close to those found in Prades (Escarre et al, 1983). Mn levels are higher than those at either Rouquet or Prades (table II). Montseny beech leaves show Fe levels similar to other beech forests (Guha and Mitchell, 1966; Heinrichs and Mayer, 1980), but for Mn we observed relatively low values. Fir has low Mn concentrations. As expected, at Montseny the beech leaves are richer in $\mathrm{Fe}$ than the leaves of the holm oak or the fir.

The $\mathrm{Mn}$ requires further comment. We know that micronutrients are, in general, more available in areas with a slightly acid 
Table II. $\mathrm{Mn}, \mathrm{Fe}$ and $\mathrm{Zn}$ concentrations in the different biomass fractions reported from other studies at 3 different locations.

\begin{tabular}{|c|c|c|c|c|c|}
\hline Species & Fraction & $M n$ & $\mathrm{Fe}$ & $Z n$ & Location \\
\hline & \multicolumn{5}{|c|}{$p p m$} \\
\hline Quercus ilex & $\begin{array}{l}\text { leaves } 1 \text { year } \\
\text { leaves } 2 \text { years } \\
\text { twigs } \\
\text { branches } \\
\text { stem wood }\end{array}$ & $\begin{array}{r}290 \\
440 \\
160 \\
80 \\
60\end{array}$ & $\begin{array}{r}150 \\
210 \\
200 \\
90 \\
60\end{array}$ & $\begin{array}{l}50 \\
70 \\
60 \\
50 \\
20\end{array}$ & $\begin{array}{l}\text { Le Rouquet } \\
\text { (Rapp, 1971) }\end{array}$ \\
\hline Quercus ilex & $\begin{array}{l}\text { leaves } 1 \text { year } \\
\text { leaves } 2 \text { years } \\
\text { twigs } 1 \text { year } \\
\text { twigs } 2 \text { years }\end{array}$ & $\begin{array}{l}891 \\
900 \\
472 \\
365\end{array}$ & $\begin{array}{r}107 \\
130 \\
101 \\
93\end{array}$ & $\begin{array}{l}38 \\
47 \\
34 \\
24\end{array}$ & $\begin{array}{c}\text { Prades } \\
\text { (Escarré et al } \\
1983 \text { ) }\end{array}$ \\
\hline Fagus sylvatica & $\begin{array}{l}\text { leaves } \\
\text { branches wood } \\
\text { stem wood }\end{array}$ & $\begin{array}{r}1800 \\
420 \\
260\end{array}$ & $\begin{array}{l}300 \\
120 \\
270\end{array}$ & $\begin{array}{l}46 \\
10 \\
11\end{array}$ & $\begin{array}{c}\text { Solling } \\
\text { (Heinrichs and } \\
\text { Mayer, 1980) }\end{array}$ \\
\hline \multirow[t]{2}{*}{ Picea abies } & $\begin{array}{l}\text { leaves } 1 \text { year } \\
\text { leaves } 2 \text { years } \\
\text { twigs } 1 \text { year }\end{array}$ & $\begin{array}{l}560 \\
980 \\
440\end{array}$ & $\begin{array}{l}150 \\
220 \\
220\end{array}$ & $\begin{array}{l}34 \\
33 \\
59\end{array}$ & $\begin{array}{c}\text { Solling } \\
\text { (Heinrichs and } \\
\text { Mayer, 1980) }\end{array}$ \\
\hline & $\begin{array}{l}\text { twigs } 2 \text { years } \\
\text { stem wood }\end{array}$ & $\begin{array}{l}510 \\
160\end{array}$ & $\begin{array}{l}340 \\
180\end{array}$ & $\begin{array}{l}83 \\
21\end{array}$ & \\
\hline
\end{tabular}

$\mathrm{pH}$ (Sutcliffe and Baker, 1979). This is reflected in the biomass content of these nutrients. Nihlgård and Lindgren (1977) studied 3 beech forests growing on different soil types and found that $\mathrm{Mn}$ oxidizes and precipitates, becoming unavailable to plants at a $\mathrm{pH}$ higher than 6. As a result, the concentrations and contents of this element in plant tissues are higher in beech forests growing on acid soils where production is also low. Olsen (1948) observed that, on calcareous soils, beech leaves show concentrations of $\mathrm{Fe}$ higher than those of $\mathrm{Mn}$, while on acid soils, the reverse is true. Passama (1970) analysed $M n$, $\mathrm{Fe}$ and $\mathrm{Zn}$ in the leaves of holm oaks growing on acid and calcareous soils and found that there was a general tendency for the levels to increase with acidity, especially for Mn.
Thus, the $\mathrm{Mn}$ concentrations in the Montseny holm oak could be a consequence of the relatively high amounts of $\mathrm{Mn}$ in the soil and the low $\mathrm{pH}$ values when compared with the other sites with holm oak forests studied by Lossaint and Rapp (1971) and Escarré et al (1983). Incidentally, the beech and fir stands studied here have relatively less acidic soils than at the other European sites where the same species have been studied, and this may explain why $\mathrm{Mn}$ levels are lower in Montseny.

\section{Twigs, branches and stems}

The twigs in the holm oak stands have $\mathrm{Mn}$ and $\mathrm{Zn}$ concentrations similar to those found in Prades (Escarre et al, 1983) and higher concentrations of $\mathrm{Fe}$. 
The concentration of $\mathrm{Cu}$ in the twigs is higher than that of the leaves for holm oak and fir, but for beech the reverse is true. In general, fir branches are relatively rich in micronutrients. The observations of micronutrient accumulation, and especially of $\mathrm{Fe}$, in relation to the age of the twigs, made by Heinrichs and Mayer (1980) for Picea abies forests, suggest a storage function. Our results for fir could also be the result of the storage of the less mobile elements in that biomass fraction.

The stem wood is poor in micronutrients in the 3 species, except for $\mathrm{Cu}$ in the beech (table I).

Using the data collected by Rodin and Bazilevich (1967) on temperate forests, holm oak leaves contain, in general, lower concentrations than are found in the leaves of deciduous trees and are closer to the concentrations found in conifers; however, the holm oak wood is richer than that of deciduous trees. This pattern is not observed clearly in our Montseny data.

\section{Other fractions}

We have considered the bark, inflorescences and fruits for the holm oak alone (table I). Our results do not require much comment. It is worth noting, however, that $\mathrm{Fe}$ and $\mathrm{Zn}$ are present in relatively low concentrations in acorns, showing a pattern similar to that observed for $\mathrm{Na}$ (Ferres, 1984) in the same stand. Mn and, especially, $\mathrm{Zn}$ have quite high values in the inflorescences.

\section{Micronutrient levels in the biomass}

The micronutrient levels in the biomass obviously depend on the quantity of the biomass. In figure 1 we show the distribution of $\mathrm{Mn}, \mathrm{Fe}$ and $\mathrm{Zn}$ in the holm oak. Table III shows data from the different types of forests. Note that the $3 \mathrm{holm}$ oak forests are rather poor in $\mathrm{Mn}$ and $\mathrm{Fe}$ when compared with the $F$ sylvatica and $P$ abies stands. However, they are relatively rich in $\mathrm{Mn}$ when compared with stands of Mediterranean pines.

Table III. Above ground contents of $\mathrm{Mn}, \mathrm{Fe}$ and $\mathrm{Zn}$ recorded in a range of studies.

\begin{tabular}{lcccll}
\hline \multicolumn{1}{c}{ Species } & Mn & $\begin{array}{c}\text { Fe } \\
\text { Kg.ha }-1\end{array}$ & $Z n$ & \multicolumn{1}{c}{ Location } \\
\hline Quercus ilex & 19 & 18 & 6 & Le Rouquet (1) \\
Quercus ilex & 15 & 8 & 2 & Prades (2) \\
Quercus ilex & 33 & 15 & 3 & La Castanya (3) \\
Fagus sylvatica & 29 & 5 & - & Öved (4) \\
Fagus sylvatica & 123 & 81 & 4.6 & Solling (5) \\
mixed forest & 41 & 3.4 & 5 & Hubbard Brook (6) \\
Pinus pinea & 2.6 & 24.5 & 4.2 & Montpellier (7) \\
Pinus halepensis & 1.8 & 34 & - & Grabells (8) \\
Picea abies & 85 & 65 & 12 & Solling (5) \\
Picea mariana & 12 & 11 & 3 & Schefferville (9) \\
Quercus stellata & 89 & - & - & Oklahoma (10) \\
\hline
\end{tabular}

(1) Rapp (1971); (2) Escarré et al (1983); (3) present study; (4) Nihlgård and Lindgren (1977); (5) Heinrichs and Mayer (1980); (6) Whittaker et al (1979); (7) Rapp and Cabanettes (1980); (8) Rapp (1978); (9) Allan and Rencz (1982); (10) Johnson and Risser (1974). 

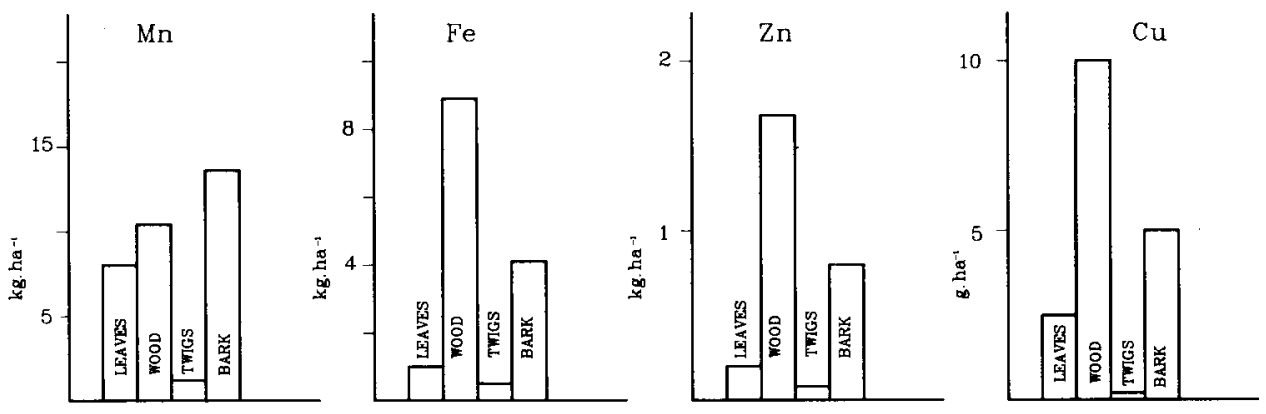

Fig 1. Amount (kg. ha $\left.{ }^{-1}\right)$ of $\mathrm{Mn}$, Fe and $\mathrm{Zn}$ measured in the different fractions of the evergreen oak forest of La Castanya.

\section{CONCLUSION}

The concentration ranking of the micronutrients studied in the Montseny stands is the same for all 3 types of forest: $\mathrm{Mn}>\mathrm{Fe}>\mathrm{Zn}>\mathrm{Cu}$. The holm oak shows values similar to those found at other sites with the same species, except for Mn. The high levels of $\mathrm{Mn}$ in Montseny are probably due to low soil $\mathrm{pH}$ and the resulting high concentrations of soluble $\mathrm{Mn}$ in the soils.

Usually, high micronutrient concentrations are found in the most metabolically active tissues: the leaves and twigs. The levels in fir branches are the exception. $\mathrm{Mn}, \mathrm{Fe}$ and $\mathrm{Zn}$ levels increase with leaf age as do the other accumulating elements such as $\mathrm{Ca}$ and $\mathrm{Na}$ (Ferres, 1984). On the other hand, $\mathrm{N}$ and $\mathrm{P}$ are translocated more easily. Concentrations of these metals in the wood decrease as the diameter increases, as do the marcronutrients, because of a dilution phenomenon.

The wood and bark of the holm oak forest contain a large proportion of the nutrient content, as is usual in forest ecosystems, because of their great quantity. The main part of the Fe, $\mathrm{Zn}$ and $\mathrm{Cu}$ is found in the wood, bark, leaves and twigs. $\mathrm{Mg}, \mathrm{Na}, \mathrm{N}$ and $\mathrm{K}$ show the same pattern. The highest quantities of $\mathrm{Mn}$ and $\mathrm{Ca}$ are found in the bark.

As for the macronutrients, the foliar micronutrient levels represent an important percentage of the total amount of these elements if we bear in mind that the leaf biomass is only $3.8 \%$ of the total biomass of this forest. The percentage of $\mathrm{Mn}$ located in leaves is especially high and is greater than the percentage of $\mathrm{N}$. Leaf nutrients have a higher turnover rate than the nutrients stored in other biomass fractions.

Our 3 forests show different micronutrient allocational patterns, and this is probably related to their different modes of life (deciduous, evergreen conifers, broad-leaved evergreens). Beech tends to have higher concentrations of $\mathrm{Mn}$ and $\mathrm{Fe}$ in the leaves. Holm oak has a relatively even distribution (except for the high levels of $M n$ in leaves). Fir, as other conifers, shows high micronutrient levels in the branches.

\section{ACKNOWLEDGMENTS}

This work was supported financially by the CAICYT. We thank Estació Biológica de la Castanya de la Generalitat de Catalunya and the Servei de Parcs Naturals de la Diputació de Barcelona. We also thank Dr Miller and 
Dr Killham for their advice and facilities given to some of our analytical work done in their laboratories (Forestry and Soil Science Departments, Aberdeen University) and $M$ Compte and $M$ Gumbao for the revision of the English version.

\section{RÉFÉRENCES}

Allan NDA, Rencz AN (1982) Concentration, mass and distribution of nutrients in a subarctic Picea mariana-Cladonia a/pestris ecosystem. Can J For Res 12, 947-968

Allen SE, Grimshaw HM, Parkinson JA (1974) Chemical Analysis of Ecological Materials. Blackwell, Oxford

Denaeyer de Smet S (1971) Teneurs en éléments biogènes des tapis végétaux dans les forêts caducifolièes d'Europe. In: Productivité des écosystèmes forestiers. Actes Coll Bruxelles (Écologie et Conservation 4), (Duvigneaud $P$, ed) Unesco, 515-526

Escarre A, Gracia C, Terradas J (1983) Structure and dynamics of evergreen-oak forest ecosystems. In: Dynamics of Forest Ecosystems. European Science Foundation. Uppsala 21-24

Ferres LL (1984) Biomasa, producción y mineralomasas del enzinar montano de La Castanya (Montseny). Doctoral Thesis Dept, Ecologia, Universitat Autònoma de Barcelona, Bellaterra

Guha MM, Mitchell RL (1966) The trace and major element composition of the leaves of some deciduous trees. II. Seasonal changes- Plant Soil 24, 90-112

Heinrichs H, Mayer R (1980) The role of forest vegetation in the biogeochemical cycle of heavy metals. J Environ Qual 9 , 111-118

Johnson FL, Risser PG (1974) Biomass, annual net primary production, and dynamics of six mineral elements in a post Oak-Blackjack oak forest. Ecology 55, 1246-1258
Kramer JK, Koslowski TT (1979) Physiology of Woody Plants. Academic Press, New York, $811 \mathrm{p}$

Larcher W (1977) Ecofisiologia vegetal. Omega, Barcelona, $305 \mathrm{p}$

Lossaint P, Rapp M (1971) Répartition de la matière organique, productivité et cycles des éléments minéraux dans des écosystèmes forestiers. Actes Coll. Bruxelles: Ecologie et Conservation, 4 UNESCO

Nihlgård B, Lindgren L (1977), Plant biomass, primary production and bioelements of three mature beech forests in South Sweden. Oikos 28, 95-104

Olsen C (1948) The mineral, nitrogen and sugar content of beech leaves and beech leaf sap at various times. CR Lab Carlsberg Sér Chim 26, 197-230

Passama L (1970) Composition minérale de diverses espèces calcicoles et calcifuges de la région méditerranéenne française. Oecol Plant 5, 225-246

Rapp M (1971) Cycle de la matiere organique et des élements mineraux dans quelques écosystèmes méditerranéens. Editions du CNRS, Paris, $184 \mathrm{p}$

Rapp M (1978) El ciclo biogeoquimico en un bosque de pino carrasco. In: Ecologia forestal (P Pesson, ed) Ediciones MundiPrensa, 97-118

Rapp M, Cabanettes A (1980) Biomasse, minéralomasse et productivité d'un écosystème à pins pignons (Pinus pinea, L) du littoral méditerranéen. Acta Ecologica. Oecol Plant 15, 151-164

Rodin LE, Bazilevich NI (1967) Production and Mineral Cycling in Terrestrial Vegetation. Oliver and Boyd, Edinburgh and London, $228 p$

Sutcliffe JF, Baker DA (1979) Las plantas y las sales minerales. Cuadermos Biologia. Omega, Barcelona, $67 \mathrm{p}$

Whittaker RH, Likens GE, Bormann FH, Eaton JS, Siccama TG (1979) The Hubbard Brook ecosystem study: forest nutrient cycling and element behaviour. Ecology 60, 203-220 